
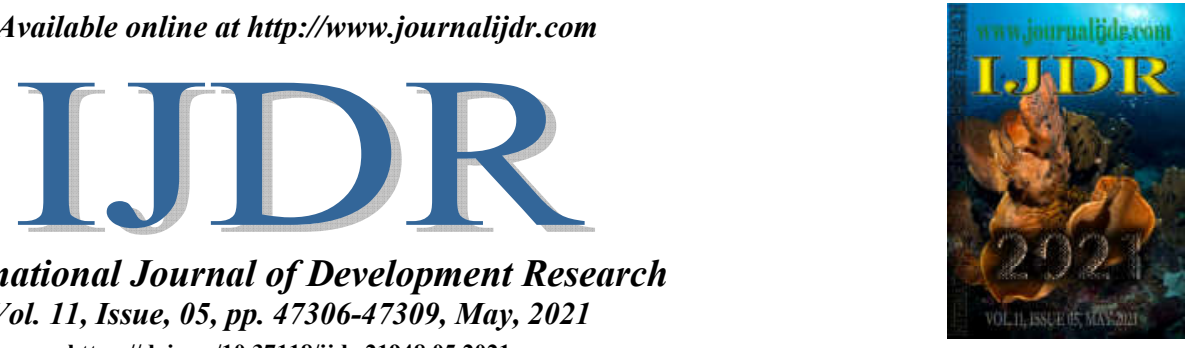

ISSN: 2230-9926

International Journal of Development Research

Vol. 11, Issue, 05, pp. 47306-47309, May, 2021

https://doi.org/10.37118/ijdr.21948.05.2021

\title{
AN APPLICATION OF GOTHIC ELEMENTS IN RUDYARD KIPLING'S “MY OWN TRUE GHOST STORY"
}

\author{
*Arunakumari S. \\ Assistant Professor, DWH- FLS, JSS Academy of Higher Education and Research Mysuru, Karnataka
}

\section{ARTICLE INFO}

\section{Article History:}

Received $27^{\text {th }}$ February, 2021

Received in revised form

$08^{\text {th }}$ March, 2021

Accepted $11^{\text {th }}$ April, 2021

Published online $30^{\text {th }}$ May, 2021

\section{Key Words:}

Street People; Pregnancy; Prenatal care; Women's health; nursing professionals.

*Corresponding author: Arunakumari $S$.

\begin{abstract}
This paper aims to find the Gothic elements in Rudyard Kipling, selected short story. After the first reading of the short story "My own true ghost story" shows a lot of gothic elements. The analysis of this Gothic story will show how young man haunted by Dak Bungalow because of the game room, doolie bearers walking sound and dark winter night with rain-affected to the young hero of this story. In all Victorian gothic stories and novels, young protagonist characters are only suffered in the example of H G Wells story The Red Room hero suffered by Shadow and long corridors, Wuthering Heights by a young ghost with Dark Romance, haunted rooms, windows, churchyards, graveyards, vault these are common places. But in Rudyard Kipling's story My Own True Ghost stories Young British Protagonist or Narrator of this story haunted by the Bungalow take takers Kanshamas, who is old as the building, they told old stories about a British officer who visited, stayed this Dak Bungalow, and how they lived now also as a ghost and he tried to see this but that particular he fell from the steps when he opens his eye, Khansams is sitting beside him and he thought this is unanswered place.
\end{abstract}

Copyright ${ }^{(C)}$ 2021, Arunakumari $\mathbf{S}$. This is an open access article distributed under the Creative Commons Attribution License, which permits unrestricted use, distribution, and reproduction in any medium, provided the original work is properly cited.

Citation: Arunakumari S. 2021. "An application of gothic elements in rudyard kipling's "my own true ghost story", International Journal of Development Research, 11, (05), 47306-47309.

\section{INTRODUCTION}

Gothic literature arose in Europe in the 18th century as a result of Romanticism in literature. This is a narrative that prioritizes emotional experience, combining horror and thrill, tragedy and love. The Gothic is known for its gruesome legends and darkly picturesque surroundings. It takes its name and stylistic cues from the middle Ages' Gothic architectural style, which features crumbling cathedrals, lonely castles, and decaying spaces. The combination of past and present is at the heart of Gothic fiction. As a result, it frequently occurs with periods of a historical transition, such as the end of the medieval age and the start of industrialization. Even though human technical breakthroughs appear to increase his power, the past threatens us. The monstrous sculptures stealthily inserted into most of the finest later Gothic church work of the time can fairly evaluate the prevalence and intensity of the medieval horror-spirit in Europe, intensified by the dark despair brought by waves of disease. The daemonic gargoyles of Notre Dame and Mont St. Michel are among the most notable example. And it must be remembered that throughout the era, there was the widespread unquestioned belief in all forms of the mysterious, again from simplest of Christian ideas towards the most horrific maladies of practicing witchcraft and black magic, between both learned and illiterate people alike. When our own old English time Beowulf story is full of an eldritch oddity, the Scandinavian Eddas and Sagas thunder with cosmic dread and tremble with the stark fear of Ymir and his shapeless progeny.
Dante is a forerunner in the classical depiction of ghastly atmospheric, but there would be more than only several traces of strange fear in the landscape in Spenser's majestic stanzas. We can perceive a great deal of influence of the demoniac on the popular imagination in Elizabethan theatre, with its Dr. Faustus, the witches in Macbeth, the ghost in Hamlet, and the horrifying grotesqueness of Webster; a hold enhanced by the very real fear of living witchcraft, whose terrors, first wildest on the Continent, begin to resound loudly in English ears as the witch-hunting crusades of James the First era witcheraft is quite common. If you think about it, it rather astonishes that strange narration as a permanent and officially recognized literary style took so long to emerge. The urge and atmosphere are as ancient as man, yet the traditional bizarre tale is a kid of the $1700 \mathrm{~s}$. Whereas this word "Gothic" evokes ideas of ghostly and gloomy doom, the style is also not solely on fear. Let us just take a glance at what renders it so appealing by tracing the genre's history via ten of the eeriest and heartbreaking pieces that have shaped it. Gothic started in English literature with the publication of Horace Walpole's "In the Castle of Otranto". Germans romantic reacted quickly to Walpole's influences and quickly becomes the watchword for the strange and grotesque. The great Mrs. Barbauld, then Miss Aikin, was one of the first imitators in England, publishing an incomplete piece called "Sir Bertrand" in 1773, wherein the threads of actual dread are stroked without a sloppy hand. An aristocrat approaches a weird and historic turret-mounted castle where doors open and close, and whose bluish will-o'-the-wisps lead up mystery stairs towards cold dead 
fingers and living black statues, enticed by a tolling bell and distant light on a dark and lonely moor. Eventually, Sir Bertrand arrives in a casket with a dead lady, whom he kisses; and after the kiss, the image dissolves to reveal lavish apartments in which the lady, restored to life, hosts a dinner in honor of her savior. The Old English Baron, by Clara Reeve, published in 1777, was an even more prominent progeny of Walpole's Otranto. Mrs. Sophia Lee's The Recess, written in 1758, contains a historical aspect, centered on Mary, Queen of Scots' twin daughters; and, while lacking the uncanny, utilizes the Walpole setting and technique with amazing finesse. 5 years, earlier all previous lights pale in comparison to the rise of a new light of entirely superior order-Mrs. Ann Radcliffe (1764-1823), whose famous novels made dread and suspense fashionable, and who set new and higher standards in the arena of ghastly and anxious mood, although an annoying habit of finally killing her phantoms with a labored mechanistic explanation. Joseph Sheridan Le Fanu was a popular horror and ghost story author in the nineteenth century. Carmilla (1872), a female lesbian Dracula fiction, influenced Bram Stoker's Dracula (1897). Enlightenment intellectuals were upset by Gothic literature's "false" facts because of its superstitious components, which combined history with fiction. The novel "made some of them scream a little, but all in generally scared to go to sleep o' night time," according to Cambridgeshire reports. Many writers contributed to the genre's legitimacy by imbuing it with realism to lend respect to their gothic elements. The gothic style used by all English literature example America, German, etc. The origins of Gothicism have changed over occur as a consequence of the writers' and their eras' social, political, and personal events. Depending on the location or environment, including the Town Of Salem witchcraft, the American Revolutionary War, the Vietnam War, the post-Zombie apocalypse, or unrequited love (a timeless theme), Gothic fiction uses basic characteristics to keeps readers returning with more.

Some of the American gothic literature work shows the haunted nature examples

Deep into that darkness peering, long I stood there wondering, fearing, Doubting, dreaming dreams no mortal ever dared to dream before; But the silence was unbroken, and the darkness gave no token, And the only word was there spoken was the whispered word, 'Lenore!'

-- The Raven, Edgar Allan Poe

"I perceived myself outside my body-- saw my body near me, but certainly not containing me...I was a great cloud-- if I may express it that way-- anchored to my body. It appeared to me, at first, as if I had discovered a greater self of which the conscious being in my brain was only a little part."

\section{-- The Stolen Body, H.G. Wells}

Imperial gothic: Some authors fled into such a slightly backward world of the dark ages of feeling, chivalry, and dread during the early Victorian era of steam engines and the electrical telegraph, typically modeled on Ann Radcliffe's and Walter Scott's Medieval Gothic. So many of the great Gothic fiction,such as Nesbit's novella and Charlotte Perkins Gilman's classic The Yellow Wallpaper (1892), concerns about domestic spatial violations. When women's experiences are limited to the homes, they may be more sensitive to unhappy female life after death who are still housebound after death. Not that everybody Victorian Gothic hides this uncertainty behind luminal windows and doors or in phantom rooms. Gothic offers a good haven both for ancient demonic and modern psychological distress at an age of increasing theological doubt, spiritualistic experimentation, and imperial worries. Authors can prioritize mystery and ambiguity over-explanation and clarity. The rise of social Darwinism coincided with the reemergence of imperial gothic in connection with Victorian excitement about geographical expansion; disagreements and conflicts caused by "the new imperialism"; revived interest in the occult and supernatural; and the birth of eugenics, as well as the social Darwinism movement, as well as cultural and racial issues deterioration. In nineteenth-century Britain, mysticism, degeneracy, irrationality, and barbarism came to describe the non-western 'other.' In Gothic works including Jane Eyre, The Moonstone, Dracula, and Heart of Darkness, 'otherness' and Empire were presented. The phrase "imperial Gothic" describes latenineteenth-century literature established within Colonial Government that incorporates and adopts themes of Gothic novels such as a dreary, foreboding atmosphere; harsh, dictatorial men; dramatic forms of brutality or retribution; and the presence of the occult or supernatural. Imperialism and occultism both served as faux religious faiths, but their union in imperialist Gothic is not the same as looking for better religions. Imperialist romancers' descriptions of atavism and going native do not give salvationist answers for searchers pursuing religious truth; instead, they present relentless pictures of deterioration and isolation. Just like the Englishman who desecrates a church, society can fall or turn into its polar opposite. In Rudyard Kipling's "Mark of the Beast," a Hindu temple transforms into werewolves. Fictional characters' atavistic descents into the primitive appear to be fictions for just a greater regression tendency of civilization, British advancement translated become British regression. After approximately 1880 , much imperialist writing sees the Imperial as a bulwark towards new barbaric invaders, or as a "dressed for supper," a stopgap to save England from falling into barbarians. Britain started to fear the degradation of British institutions, culture, and racial "stock" after the mid-Victorian years, as they found it increasingly difficult to think of themselves as inherently developing. Personal decline or returning home, an invading of civilization with powers of savagery or demonism, and the reduction of opportunity for exploration and courage in the contemporary world are also the three important aspects of imperial Gothic. The paranormal or supernatural, generally indicative of personal regress, frequently manifests in the romances of Stevenson, Haggard, Kipling, Doyle, Bram Stoker, and John Buchan. In imperialist settings, it manifests itself. Lewis Wurgaft notes Kipling's "Phantom Rickshaw" as an example of Anglo-Indian fiction that regularly deals with "inexplicable curses, demonic possession, and ghostly visitations," and innumerable such tales were established in Burma, Egypt, and India, Nigeria, as well as other territories of the Empire.

My Own True Ghost Story: This story was initially printed in The Week's News on February 25, 1888, and was later collected in Volumes 5 of the Indian Railway Library - The Phantom'Rickshaw and other Haunted Stories the following year. It was first published in 1895 in We Willie Winkie and Other Stories and has since appeared in several versions of such a book. "My Own True Ghost Story," by Rudyard Kipling, used allusions, which he makes through senses of sight and sound, allows him to purposefully deceive his reader into thinking his narrative contains ghosts. Kipling is capable of creating a reality in which simple noises are unpleasant and terrifying to individuals through his careful use of vocabulary. He accomplishes this by employing important words and expressions that elicit an emotive reaction from readers. The narrators spend the nighttime in an old dâk-bungalow that has a menacing vibe to it. He heard the 'uncommon' sounds of a billiard game being played inside the empty room next door through the night. The old servant informs him in the morning that there used to be a billiards room inside, and also that on night one of the sahibs (British official) had died across the tabletop. The narrator is thrilled to have come across what appears to be a true ghost story. And then he hears it once again: a small rat racing back and forth inside the ceiling cloth, and his imaginations took over. Rudyard begins the story by recounting Indian ghost stories that generally take place along Pakistan's Grand Trunk Road. Whenever tourists lived in bungalows across its route while passing through place to place have always been the focus of the ghost stories. Kipling chooses to lodge at a guesthouse called Katmal, which means "bedbug" in Hindi. Kipling portrays these bungalows mostly along Grand Trunk Road as "extremely ancient" and "usually unclean" in retrospect. Although many haunting buildings are painted beneath comparable lighting, Kipling purposely utilizes the adjectives "ancient" and "unclean" to evoke a sense of unease. In a similar vein, Kipling says that the Katmal bungalow is not suitable for someone with a "sensitive hide." 
According to Kipling alone personal cannot stay in this Katmal Dak Bungalow, because it is a very frightening place if they won't stay here, they want to marry, which means the couple can stay here. The story starts with the English narrator describe a place like this

"As I came through the Desert thus it was--

As I came through the Desert.

the City of Dreadful Night".

The narrator said, I entered a desolate and terrible place, anyway he is an English narrator he told about the Indian ghost and he explains "in this land, ghosts who take the form of fat, cold, pobby corpses, and hide in trees near the roadside till a traveler passes. Then they drop upon his neck and remain. There are also terrible ghosts of women who have died in child-bed. These wander along the pathways at dusk, or hide in the crops near a village, and call seductively". It means the Indians ghost cannot make frightening the English ghost, but English ghosts are afraid of both Indian and English ghost. In India near every railway station ghosts are there because of Bungalows particularly in Simla, Lahore, Missouri, these are British official's guest houses, when they travel from one place to another place, they stayed in these bungalows are "objectionable" means unpleasant places.

"They are generally very old, always dirty, while the khansamah is as ancient as the bungalow. He either chatters senilely or falls into the long trances of age. In both moods he is useless. If you get angry with him, he refers to some Sahib dead and buried these thirty years, and says that when he was in that Sahib's service not a khansamah in the province could touch him. Then he jabbers and mows and trembles and fidgets among the dishes, and you repent of your irritation".

Once the narrator enters this place to this night he observed and explains, Khansamah is as old as this bungalow, he is a guard and cook of this place, if you will scold him about this dirty thing, Khansamah started to tell the story of Sahibs, who came to stay here and how they died in this place, suddenly this old man asked the hero, what shall I prepared for dinner, it shows that Khansamah lived and imagine in the past time, so past and present comes in the same time something bad, the frightening atmosphere will create the example, Victorian gothic stories happed because of modern railway and telegraph machine did not handle by the guard. The narrator explained this bungalow belongs to the government, and when he entered snakes have invited him, the book maintained by Khansamah was used 15 months ago. English narrator found out that this place was visited by local British officials, the windowpane is not working, all furniture refilled with dust old s Khansamah. It is raining time and old man brings food it is also mixed of English and local food shows that the power of British in food. The narrator observed in this house, only three rooms, and walls made of wood, old house or bungalow near to railway station, the graveyard also season is winter, moorland, footsteps echoed, a door cannot open and because of wind it can move, no candles or lamps, very dark shows all are gothic elements. AS the narrator went to sleep he heard

"I heard the regular--"Let--us--take--and--heave--him--over" grunt of doolie- bearers in the compound. The first one doolie came in, then a second, and then a third. I heard the doolies dumped on the ground, and the shutter in front of my door shook. "That's someone trying to come in," I said. But no one spoke, and I persuaded myself that it was the gusty wind. The shutter of the room next to mine was attacked, flung back, and the inner door opened. "That's some Sub- Deputy Assistant," I said, "and he has brought his friends with him. Now they'll talk and spit and smoke for an hour."

When he went to bed, he listened to Doolie bearers walking sound, he thought, they bring official to stay here and he imagined that officer comes with three friends and they are playing the game in the next room but all this only imagine of the narrator. Throughout out the night, he heard the Billiard game playing by officers, how they moving chairs, table and gave stroke in the game and there talking but narrator argued with Khansamah they said ghost is here but only a rat sound, no one is ready to believe this.

"I hear every stroke of a long game at billiards played in the echoing room behind the iron-barred door. My dominant fear was that the players might want a marker. It was an absurd fear; because creatures who could play in the dark would be above such superfluities. I only know that that was my terror, and it was real".

The narrator said even though a man or couple who comes to test this bungalow, definitely will be frightened because they will think nothing is in this place with rational mid people also haunted by this bungalow. After all, he heard the billiard game played by people in another room but once he went to the room one is there, but the visitors mined filled this sound including the narrator, this experience is absurd. The narrator earlier made a plan to stay here 3 days but last night he did not sleep, he is vacating then he asked Khansamah about the night sound but the old man replied

"By the way, khansamah," I said, "what were those three doolies doing in my compound in the night?"

"There were no doolies," said the khansamah."

The narrator wanted to check the room and he went upstairs visited the room only chairs and table no one is there, then old man explained sahibs build this house, while they making railroad and they used to stay here, all are dead now it shows that dead, past things comes to the present to haunt, this is the best example, but one officer died in this bungalow old man said to the narrator like this

"It is long ago, but I remember that one Sahib, a fat man and always angry, was playing here one night, and he said to me:-'Mangal Khan, brandy-pani do,' and I filled the glass, and he bent over the table to strike, and his head fell lower and lower till it hit the table, and his spectacles came off, and when we--the Sahibs and I--ran to lift him he was dead. I helped to carry him out. Aha, he was a strong Sahib! But he is dead and I, old Mangal Khan, am still living, by your favor."

The old man explained to the narrator how Mangal Khan died, a very angry man, who is working in railway it shows the encounter of the modern railway and people cannot accept as it is, and they will die, at last author got this information and wrote this story. The narrator says, moreover, that Kadir Baksh accepted a bribe from the doolie bearers and that it was his... the khansamah let them stay the night because of his intelligence. He claims that Kadir Baksh has no sense of ethics, a claim that he makes on behalf of the colonial period overall. The locals seem to be loyal, which they try to take advantage of because of their gain.

The speaker tries to extract information from the khansamah, but he lost his temper and scatters the sad death including its fat engineer sahib across India's scenery. The writer is distressed by the revelation that there is no ghost, implying that facts have taken away the spiritual potential that he may have had. After covering the review, we'll move on to a brief contrast of Dickens' Signal Man and Rudyard Kipling's My Own True Ghost Story. The Signal Man by Dickens and My Own True Ghost Story by Kipling are quite close in terms of the use of gothic reasons and the atmosphere in which the stories happen. The railways, on the other hand, weren't considered as strong or majestic in the Ghost Story when spoken by the khansamah. It turned out it was allusions to the empire's glory that he uses to subvert the narrative. There is indeed a feeling of obsequiousness at the same time as there is a suggestion that the colony is questioning the monarchy that has set down frameworks and judgments around its scenery.

\section{CONCLUSION}

The horror story evolved in an embedded plot in fiction or miscellany into a distinct genre of short fiction in the 19th century, encompassing both the small, freaky tale and the technically elaborate and 
psychologically sophisticated tale. The Victorian gothic has a long and varied history of dealing with male / female problems. Both women and men authors have used the Gothic - a genre that explores the dark side of personalities, societies, and nations as a barometer of societal stress and anxiety - to question socially determined and institutionally ingrained attitudes and laws relating to women and men. Death is depicted throughout the Victorian Gothic in a way that is closely linked to representations of rationality. The way we read death and the anxieties it causes demonstrates how much our selfidentity is based on death narratives. In the late 1800s, Speech and Talk experts used a series of creepy or haunting analogies to describe the elusive nature of vocal development as well as the causes and remedies of stammering speech.

\section{REFERENCES}

Brantlinger, Patrick. Rule of Darkness: British Literature and Imperialism, 1830-1914. Ithaca: Cornell University Press, 1988.

Hamm, Geoffrey. "Revisiting the Great Game in Asia: Rudyard Kipling and Popular History." International Journal, vol. 68, no. 2, 2013, pp. 395-402. JSTOR.

$\mathrm{http}: / / \mathrm{www}$.writersinspire.org/content/victorian-gothic-introduction https://americanliterature.com/gothic-literature-study-guide

Kipling, Rudyard, and Carpenter Kipling Collection. The Phantom Rickshaw and Other Stories. [Philadelphia: Henry Altemus, 1898] Pdf. Retrieved from the Library of Congress, $<$ www.loc.gov/item/98000499/>. 